CATALAN REVIEW

Catalan Review

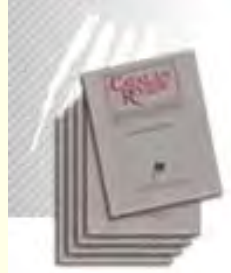

You are accessing the Digital Archive of the Catalan Review Journal.

By accessing and/or using this Digital Archive, you accept and agree to abide by the Terms and Conditions of Use available at http://www.nacs-

catalanstudies.org/catalan_review.html

Catalan Review is the premier international scholarly journal devoted to all aspects of Catalan culture. By Catalan culture is understood all manifestations of intellectual and artistic life produced in the Catalan language or in the geographical areas where Catalan is spoken. Catalan Review has been in publication since 1986 .
NORTH

AMERICAN

CATALAN

SOCIETY
Esteu accedint a l'Arxiu Digital del Catalan Review

A l' accedir i / o utilitzar aquest Arxiu Digital, vostè accepta i es compromet a complir els termes i condicions d'ús disponibles a http://www.nacs-

catalanstudies.org/catalan_review.html

Catalan Review és la primera revista internacional dedicada a tots els aspectes de la cultura catalana. Per la cultura catalana s'entén totes les manifestacions de la vida intel lectual i artística produïda en llengua catalana o en les zones geogràfiques on es parla català. Catalan Review es publica des de 1986.

\title{
Reading and writing the other side of the story in two narratives by Carme Riera Kathleen M. Glenn
}

Catalan Review, Vol. VII, number 1 (1993), p. 51-62 


\section{READING AND WRITING THE OTHER SIDE \\ OF THE STORY \\ IN TWO NARRATIVES BY CARME RIERA}

\section{KATHLEEN M. GLENN}

In her 1989 book, Molly Hite calls attention to a strategy frequently employed by contemporary women writers, that of presenting the other side of what has historically been considered "the" story, maleauthored and male-centered. Hite reminds us that stories entail a point of view and take sides, that "the coherence of one line of narration rests on the suppression of any number of "other sides", alternative versions that might give the same sequence of events an entirely different set of emphases and values» (4). By emphasizing conventionally marginal themes and charcters, writers such as Jean Rhys, Doris Lessing, Alice Walker, and Margaret Atwood deliberately violate cultural and literary traditions perceived as profoundly masculinist. Similarly Rachel Blau DuPlessis points out how twentieth-century women poets have reenvisioned classical and Judeo-Christian myths, shifting attention to the other, noncanonical side of the story. This narrative displacement "offers the possibility of speech to the female in the case, giving voice to the muted" (108). Such a change in perspective radically alters the nature of the story and its underlying assumptions. Edna St. Vincent Millay reveals that while Penelope really wept, Ulysses only pretended to, and H.D. discloses Eurydice's resentment at having her hopes dashed and being returned to death (108, IIO). Atwood's Circe complains to Odysseus of being trapped in an inexorable script: "Don't evade, don't pretend you won't leave after all: you leave in the story and the story is ruthless" (quoted in DuPlessis III). The concept of the other side of the story and the possibility of alternative scripts are relevant to the fiction of Carme Riera and in particular to several of her short narratives. The two that concern me here have appeared in various forms. Each is the opening and titular story of the volume in which it was initially 
published, Te deix, amor, la mar com a penyora (1975) and Jo pos per testimoni les gavines (1977). The two are the first and second tales of Palabra de mujer (1980), Riera's Castilian version of the Catalan originals, and both reappear in Luisa Cotoner's Te dejo el mar, the Castilian translation of the 1975 and 1977 books. There are important differences, as we shall see, between the Catalan original and the Castilian version of the second story.'

Riera and her characters have repeatedly commented on the importance of the art of seduction. Pablo Corbalán, of Joc de miralls, confesses that his primary goal as a writer is to seduce: "M'interessa d'entrada seduir el lector perquè segueixi llegint. Mitjançant l'aparença de la meva escriptura, mitjançant els signes, les ambigüitats i connotacions que li ofereix el meu discurs, envoltar-lo, conduir-lo i atracar-lo cap a mi, fer-lo meu, això vol dir seduirn (23-24). Àngela, the protagonist of Qüestió d'amor propi, is fond of declaring that "Qualsevol escriptura és una carta d'amor," "Escric perquè mestimin," "L'anhel de pervivència que ens empeny a estimar ens empeny també a crear," and "El text no és més que un pretext amorós" (2425). Riera clearly shares her characters' convictions. She also believes that literature, like a love letter, is engendered by desire ("Grandeza y miserian I48). In an effort to establish contact with others, to awaken their interest and hold their attention, she teases and tantalizes her readers, leading them on and engaging them in a ujuego de mostrar y de esconder" (Cotoner 2I). She has acknowledged that ambiguity and the element of surprise are basic to her literary endeavor: "Yo creo que la literatura que no tiene misterio ni ambigüedad, no interesa para nada... Lo que no puede ser objeto de sorpresa o de misterio, lo que es obvio, no tiene interés... Si algo no resulta sorprendente... entonces, no funciona" (Nichols 209-10,216). Riera's well-known preference for epistolary form is logical in view of her wish to establish a relationship of complicity wih her readers, as she

'The first story has been translated into English by Alberto Moreiras. See «I Leave You, My Love, the Sea as a Token, On Our Own Behalf: Women's Tales from Catalonia, ed. Kathleen McNerney (Lincoln: U of Nebraska P, 1988) 31-45. 
has remarked: «La carta sirve sobre todo para obras de poca extensión, para el tono menor, para el tono confidente, para la complicidady (Epístolas" 36). Seduction, ambiguity, and epistolarity all come together in "Te deix, amor, la mar com a penyora" and "Jo pos per testimoni les gavines,"

The fact that Te deix, amor, la mar com a penyora has gone through over thirty printings conveys some idea of the of the book's popularity. The first edition appeared in April 1975, seven months before Franco's death, and the titular story had received the Recull prize a year earlier. The members of the jury must have been surprised, even stunned, by the literary bombshell that Riera had delivered to them. The story is a letter from a young woman to her former math teacher, with whom she had fallen in love when she was fifteen. The girl's father forced a break-up of the relationship and now, eight years later, married and awaiting the birth of a child, the writer takes leave of her beloved and the sea that was a witness to their passion. We discover in the closing paragraph that the letter is addressed not to a man but to a woman. By withholding the lover's name until the last lines, Riera prolongs our assumption that whem is a man. The ambiguity of the Catalan pronoun "nosaltres," which unlike the Castilian "nosotros-nosotras" does not indicate gender, facilitates the deception.

Riera, in "Te deix," has turned on its head the oft-told tale of an adolescent girl's infatuation with an older, male teacher and has articulated the other side of this very traditional romance plot, a side that is inconceivable according to received notions of what is possible. This side is also, at least for some men, illegible. Riera has recounted how when "Te deix" was awarded the Recull prize, it was pointed out to her that an accent was missing on the name "Maria," that it should have been "Marià," the masculine form in Catalan (Nichols 210), and as recently as 1991, in his review of Te dejo el mar, Santos Alonso described the titular tale as "una historia apasionada de amor estre una alumna y un profesom (3I, emphasis added), even though the Castilian translation gives the lover's name as "María." Alonso apparently assumed that had to be a misprint for «Mario." 
These anecdotes illustrate that we interpret what we read in terms of the literary and cultural codes with which we are familiar and comfortable, and those codes have traditionally stipulated that a passionate love story must, of necessity, involve heterosexual rather than homosexual love. The alternative is unthinkable and unreadable. Riera, however, has had the temerity to violate social and sexual conventions and to marginalize hererosexual love. Apropos of Zora Neale Hurston's Their Eyes Were Watching God, Hite notes that «the priotity of the center depends entirely on the oppositional relation of center to margin... To call attention to the margin is to render it no longer marginal and consequently to collapse the center in a general unsettling of oppositional hierarchies" (12I-22). The previously mentioned anecdotes suggest just how unsettling such a decentering can be. The male characters of Riera's narratives are very minor figures. The young men the writer has dated and her husband are but shadows, mentioned in passing, and her father is reduced to a caricatural personification of the Law of the Father, remembered for his angry denunciation of his daughter and his «Aquest és el camí de la depravación (23). Thus characters that are usually regarded as major have been rendered minor, the center has become peripheral, gender distinctions have been destabilized, and the dominant has been reduced to silence so that the muted might speak.

If the passion that lies at the heart of Riera's story is transgressive, so too is the act of writing about it. Narrating this account of a love that is not sanctioned by society is a further aggression against the social fabric. It is fitting that the vehicle for the tale is a letter, inasmuch as epistolary literature abounds in transgressions: adultery in Les Liaisons dangereuses, prostitution in Clarissa, suicide in The Sorrows of Young Werther, and forbidden reading in all of these (Kauffman 229). Riera has been disruptive and has subverted the narrative norm according to which a woman writes to a man who has seduced and abandoned her. The choice of a latter is important for another reason. Reading has often been compared to voyeurism, and the comparison is most apt in the case of epistolary fiction, which is filled with portrayals of acts of reading and writing, as 
internal readers pore over letters fron their lovers and in turn write responses to them (see Altman an "Te deix" 3I-32). These private readings contained within the fictional world become public once the published texts fall into the hands of real-life readers. This reading of other people's mail, reprehensible as it may be, holds a perverse attraction. Riera appeals to our voyeuristic instinct by focusing upon a ukeyhole» experience. One of the writer's most vivid memories is of the spring day she and Maria made love while on a boat en route to Mallorca. The experience is first alluded to in the third paragraph of the story: "Enyor la mar, enyor la immensitat blavosa, la petita immesitat blavosa que semblava entrar-se'n a la cabina per l'ull de bou aquell migdia de primavera, camí de l'illa" (I9, emphasis added). It is as if the sea were gazing at them through the porthole, and blueness of the water, the sky, and the beloved's eyes fuse into one. The moment is again recalled during a farewell conversation with Maria, during which the past is superimposed upon the present: "De sobte una bafarada d'olor de mar em féu marxar enmig de les ones. L'aigua trucava al vidre de l'ull de boun (24). The writer's inability to see the sea from her window in Barcelona underscores her feeling of separation fron her lover in Palma. ${ }^{2}$

Vision is highlighted in the two opening paragraphs of "Te deix," each of which begins with a reference to what cannot be seen and is longed for: "Des d'aquí, des de la meva finestra, no puc veure la mar" and "No puc veure la mar perquè roman, enfora d'aquí, a l'altre canto de la ciutat" (19). The image of a woman seated at a window brings to mind the title of Carmen Martín Gaite's examination of Spanish literature from a feminine point of view, Desde la ventana, and Dali's Girl at the Window, and it evokes the idea of solitude and enclosure as a female figure, shut in, looks out upon a world that is not hers.' Sen-

${ }^{2}$ Cotoner interprets the sea as a symbol of unattainable beauty and an emblem of desire $(\mathrm{I} 4,33)$. It also is described as protective and nurturing: «agombola, com una dida" ("Te deix" 19).

${ }^{3}$ A rendition of the Dali painting adorns, appropriately, the cover of Martín Gaite's book, published in 1987 . 
sing that she will die in childbirth, the writer of "Te deix" asks that the name Maria be given to her child and that she not be buried but that her remains be returned to the scene of their lovemaking: "vull, també, que llencin el meu cos a la mar, que no l'enterrin. Et prego que en aquell redós on l'aigua espià el nostre amor, llencin les meves despulles al fondal d'immensitat il-limitada» (36). Her request bespeaks a desire to be rejoined, at last, with the sea and her lover.

One of the epigraphs for Te deix is a quotation fron the Greek philosopher Empedocles: "Jo era a la vegada arbre i ocell, al-lot i al-lota, peix mut dins la mar." Cotoner reads it as an affirmation of the radi$\mathrm{cal}$ ambiguity of all that exists and the necessary multiplicity of points of view (22), and Riera has commented that for her the quotation is a statement of androgyny: "Yo quería resumir el artista, es decir, el andrógino. Por eso decía que éramos dos cosas a la vez, y que la naturaleza y el arte son ambiguos por antonomasia" (Nichols 2II). The longing to know no bounds, to be both male and female, and to partake of earth, sea, and water, three of the immutable elements identified by Empedocles, indicates an unwillingness to accept limits of any kind.

While "Te deix" presents the other side of the traditional romance plot, "Jo pos per terstimoni les gavines" presents the other side of « $\mathrm{Te}$ deix," and the two accounts cannot be reconciled. The second narrative begins with two brief letters whose author cannot be positively identified, because her signature is illegible. The first is addressed to the director of Laia and requests that he forward the enclosed letter and manuscript to Carme Riera, author of Te deix, amor, la mar com a penyora (which Laia had published). In the second letter, addressed to Riera, the writer confesses her amazement on reading a story that has so many points of contact with her own life:

No es pot imaginar la sorpresa enorme que em causà veure'm gairebé retratada, retratada però, per un esguard generós i benevolent... No sé qui pogué contar-li amb detalls de miniaturista uns fets, esmicolant sentiments amb tanta precisió, escamotejant-ne a la vegada uns altres, canviant-ne l'acabament. Pens que tal volta l'atzar féu que vostè imaginàs una història que s'assemblava a la meva. (Io) 
The passage is a good example of the "reveal-and-conceal" technique of which Cotoner speaks. The salmost portrayed" and the references to chance and imagination imply that the resemblance between the story and the writer's life is purely coincidental, but the assumption that someone has related to Riera the most intimate details of the writer's existence argues otherwise. We are offered two conflicting explanations - sheer invetion vs. factual testimony - and the ambiguity created allows for, even encourages, a double reading of the ensuing manuscript. The ambiguity is sustained by the closing paragraph of the letter:

Pens que tal volta aquesta història meva, corregida per vostè, reescrita si vol, pot interessar a la gent que ha llegit el seu llibre, com a testimoniatge d'uns fets reals. Tot i que a la meva edat i en la meva situació és absurd parlar de pudicitat, confiï també en la seva discreció a l'hora de transcriure noms. (Io)

The possibility that a woman who may be a character in "Te deix" has written to Riera because she believes that her history may interest readers of the 1974 story has Cervantine overtones and hints at a violation of the laws of fiction and a crossing of the boundary between the real and the imaginary, between the extratextual world of Riera and the intratextual world of the characters created by her. It should be remembered that the metafictional mode was at its height in Spain during the seventies, and "Jo pos per testimoni les gavines» was composed in Octuber 1976.

In the manuscript that follows, what was recounted in "Te deix" is now seen through the eyes of a former math teacher. Her version coincides in many respects with that given us by the person she believes to be her formen student, a girl named Marina. A number of the same incidents are mentioned and described in identical or similar words. The writer recalls Marina's «gest ple de candor malaltissa, d'innocència perversa, quasi maligna d'àngel rebel" (I6), echoing "Te deix»'s "Érem més joves, menys conscients, plens d'una innocència perversa, quasi maligna, d'àngel rebel» (20). And the 
evocation in "Jo pos" of "Un passeig vuitcentista cobert de full grogues, isolat entre uns vells murs de color ocre, murs de con vents..." (I4) parallels the earlier story's "Les fulles dels plàtans ere quasi grogues al passeig vuitcentista... M'hi sentia empresonada. Le murades, perquè són murades i no parets, dels convents...n (28) Even the window setting is similar, but with a difference. The wri ter of "Jo pos» suffers from a neurosis and periodically, when sh realizes she has touched bottom, withdraws to a sanatorium. $\mathrm{He}$ voluntary seclusion there may be an attempt to ward off total mad ness or an effort to punish herself. The description of «aquest sostri baix, aquestes quatre parets asèptiques que m'envolten... en un llor tan tancat $i$ tan petit» (12) is suggestive of a prison cell. Images of enclosure are a common metaphor for the fate of women confined in men's texts and men's houses and by men's institutions (see Gilbert and Gubar). It is in that cell, near the barred window, that she obsessively resurrects the past and writes of her love.

The writer of "Jo pos" reproaches herself for having been a coward, for having renounced happiness, for having spouted conventional, moralistic phrases in which she did not believe, and, above all, for having failed to consummate her love for Marina during the boat trip. She reveals that at age seventeen Marina committed suicide, casting herself into the sea at the same hour and at the same spot where, a year earlier, the older woman had looked upon the naked body of her beloved. But Marina still appears to her and, calling on the gulls as her witness, the writer swears that red roses now bloom upon the sea and mark the site. We do not know if what she tells us is "true." She may have blotted out the "fact" of Marina's marriage because it was too painful a reality for her to bear; she may have invent a suicide that makes Marina always faithful and exclusively hers. Her words may be no more than the ramblings of a deranged woman. "Madness" is, of course, a convenient label for behavior that does not adhere to masculine norms; it can also be a means - the only one, on occasion- of escaping those same norms.

There are significant differences between "Jo pos per testimoni les gavines" and the Castilian version, which is a revision of the pro- 
tagonist and her story." Immediately apparent in "Y pongo por testigo a las gaviotas" is the absence of the initial letters that created a metafictional frame for "Jo pos" and playfully linked it to "Te deix." Even without the letters, there is sufficient internal evidence to establish a relationship between the first two stories of Palabra de mujer, and the juxtaposition of "Te entrego, amor, la mar, como una ofrenda" and "Y pongo" is a further indication of connection." Several of the same incidents appear in the second narrative, as does the familiar description of an avenue in Palma: «El paseo decimonónico, cubierto de hojas amarillas, encajonado, solías decir, entre los muros color ocre, muros de conventos, sin ventanas... (36, emphasis added). ${ }^{6}$ The sentence exemplifies the procedure followed in the 1980 version. Deletions, additions, and several major modifications have been made. The atmosphere is more oppressive and the sense of suffocation is greater. The words "sin ventanas," for instance, imply the absence of air, light, and figurative breathing space. The most important changes are those in tone amd in the situation and (self-) portrayal of the writer. She is now confined, permanently, in a sanatorium, and the comparison with a prison is explicit: unosotros los recluidos, tenemos aún menos suerte que los presos» (33). Repeatedly she alludes to her rage, rebelliousness, violence, and aggressive words, and to her male doctors and the tranquilizers they prescribe for her. (There was no mention of doctors in "Jo pos.") They disapprove of the detailed analysis to which she submits her-

${ }^{4}$ Riera has given differing explanations of the changes. In a conversation with Nichols she expressed surprise at the fact that the initial letters did not appear in Palabra de mujer and conjectured that the publisher had eliminated them (221). During my conversation with her, however, she said that copyright problems had obliged her to rewrite the story. She added that when she starts to translate something, she often finds that the text does not "work» in Castilian and so writes a new version ("Conversation $)$ ). Cotoner's translation, also entitled "Y pongo por testigo a las gaviotas, $n$ is faithful to the Catalan original.

s The title Palabra de mujer calls to mind Annie Leclerc's Parole de femme (1974).

${ }^{6}$ As the usolías decirn indicates, at various moments in "Y pongow «the writer addresses her words to Marina. 
self and prefer that she not write, claiming that her doing so is an obstacle to recovery, but she refuses to let them silence her and turn her into a model patient (and woman?), properly submissive and passive. Although they question her side of the story (whan puesto en entredicho mi versión de los hechos" [43], she does not back down, and she does not believe them when they insist that the drowned do not visit the living. She knows better. Her rebelliousness is manifest in her regret that years ago she was not strong enough to transgress patriarchal law ("no fui capaz de transgredir la ley" [36]) or to resist society's opposition to a love considered dangerous: "Un tipo de amor, que era capaz de saltarse los preceptos establecidos, generaba desorden, llevaba consigo un germen de revolución que debía ser, inexorablemente, aplastado" (37).

Whereas the protagonist of "Jo pos" was reminiscent of Ophelia, sad and gentle, in "Y pongo" she is akin to Charlotte Bronte's Bertha, raging and raving in the attic at Thornfield where Rochester keeps her prisoner. Bertha's crime, too, was sexual in nature; she too paid dearly for her passion. Jane Eyre is a work permeated by anger (Gilbert and Gubar 336) and punctuated by Bertha's cries, which are echoed in "Y pongo" by the protagonist's screams. If Rochester describes Bertha as a monster and is repulsed by her sexuality, the protagonist of "Y pongo" is also monstrous in the eyes of the world, which finds her transgressive desire repellent and threatening. Although she knows that what she writes will never be published, she persists in writing. The setting of pen to paper and recording her history is a gesture of self-affirmation and of continued rebellion, in spite of her imprisonment. "Y pongo" is a more defiant and provocative text than was "Jo pos," and it is more radical in its transformation of the canonical heterosexual love plot with its conventionally happy ending.

Riera declared in a 1988 lecture that "Se llega a escribir literatura tras una manipulación consciente de los materiales lingüísticos, basándose en un uso no referencial, no deíctico, eso es, connotativo de los mismos, a través de la violación de la norma y de la vinculación a un código nuevo que empieza a regir cuando entramos en el 
universo literario» ( Femenino singular» [26-27]). The principles enunciated there are reflected in «Te deix, amor, la mar com a penyora," "Jo pos per testimonio les gavines," and "Y pongo por testigo a las gaviotas," narratives in which Riera has written other-wise, rejecting old conventions, codes, and clichés, violating sexual and textual norms, and rewriting narrative and social scripts. By means of a carefully calculated ambiguity she has piqued and then sustained interest in these seductive tales which articulate the other side(s) of the story.

KATHLEEN M. GLENN WAKE FOREST UNIVERSITY

\section{WORKS CITED}

Alonso, Santos. Rev. of Te dejo el mar, by Carmen Riera. Reseña 222 (Nov. I991):3I.

AltMan, Janet Gurkin. Epistolarity: Approaches to a Form. Columbus: Ohio State UP, 1982.

DUPLESSIS, Rachel Blau. Writing beyond the Ending: Narrative Strategies of Twentieth-Century Women Writers. Bloomington: Indiana UP, 1985 .

GILBERT, Sandra M., and Susan Gubar. The Madwoman in the Attic: The Woman Writer and the Nineteenth-Century Literary Imagination. New Haven: Yale UP, 1979.

HrTE, Molly. The Other Side of the Story: Structures and Strategies of Contemporary Feminist Narrative. Ithaca: Cornell UP, 1989.

KAUFFMAN, Linda. "Special Delivery: Twenty-first Century Epistolarity in The Handmaid's Tale." Writing the Female Voice; Essays on Epistolary Literature. Ed. Elizabeth C. Goldsmith. Boston: Northeastern UP, 1989. 221-44.

Nichols, Geraldine C. Escribir, espacio propio: Laforet, Matute, Moix, Tusquets, Riera y Roig por sí mismas. Minneapolis: Institute for the Study of Ideologies and Literature, 1989. 
RIERA, Carme. "Conversation with Carme Riera.» With Kathleen Glenn. Forthcoming in Catalan Review.

-. "Epístolas de mar y de sol. Entrevista con Carme Riera." With Neus Aguado. Quimera 105: 32-37.

-. "Femenino singular: Literatura de mujer." Crítica y ficción literaria: Mujeres españolas contemporáneas. Ed. Aurora López and María Ángeles Pastor. Granada: U de Granada, 1989. 25-38.

-. "Grandeza y miseria de la epístola." El oficio de narrar. Ed. Marina Mayoral. Madrid: Cátedra/Ministerio de Cultura, 1989. 147-58.

-. Joc de miralls. Barcelona: Planeta, 1989.

—. Jo pos per testimoni les gavines. Barcelona: Laia, 1977.

- Palabra de mujer. Barcelona: Laia, 1980.

-. Qüestió d'amor propi, Barcelona: Laia, 1987.

- Te deix, amor, la mar com a penyora. Barcelona: Laia, 1975.

-. Te dejo el mar. Trans. and Introd. Luisa Cotoner. Madrid: Espasa Calpe, I99I. 